\title{
Nitrogen and Potassium Fertilization Effects on Yield and Quality of Burley Tobacco ${ }^{1}$
}

\author{
G. K. Evanylo and J. L. Sims²
}

\begin{abstract}
Field studies were conducted in 1983 and 1984 at Lexington, KY to examine the effects of $N$ and $K$ fertilizer on yield and chemical quality of burley tobacco (Nicotiana tabacum L. cv. Ky 14). Treatments included: $\mathrm{NH}_{4} \mathrm{NO}_{3}$ at rates of 112,280 , and $448 \mathrm{~kg} \mathrm{~N} \mathrm{ha}{ }^{-1}$; and two sources $\left(\mathrm{K}_{2} \mathrm{SO}_{4}\right.$ and $\left.\mathrm{KCl}\right)$, each at rates of $0,112,224$, and $448 \mathrm{~kg} \mathrm{~K} \mathrm{ha}{ }^{-1}$. The following agronomic and chemical characteristics were examined: yield, price, leaf $\mathrm{N}, \mathrm{P}, \mathrm{K}, \mathrm{Ca}, \mathrm{Mg}, \mathrm{Cl}, \mathrm{Mo}$, total alkaloid, and solanesol concentrations. Cured leaf yield, price, and solanesol concentration were strongly influenced by $N \times K$ interactions. Each was raised by increasing $N$ rates when no $K$ was applied; however, at higher $K$ levels, increasing $N$ rates resulted in smaller price increases, no yield changes, and reductions in solanesol concentrations. Reductions in cured leaf Mo concentration relative to $N, K$, and $M g$ levels with increasing $K$ fertilization beyond $0 \mathrm{~kg} \mathrm{ha}^{-1}$ were exaggerated as $\mathrm{N}$ rates were raised. No effect of $N$ rates on total alkaloids or solanesol concentrations were noted while increased $\mathrm{K}$ rates increased concentrations of both. Greater cured leaf yields and $\mathrm{Mo}$ concentrations were achieved with $\mathrm{KCl}$ than with $\mathrm{K}_{2} \mathrm{SO}_{4}$. The positive effect of $\mathrm{KCl}$ on Mo concentration at low $\mathrm{N}$ application rates was reduced by increased $\mathbf{N}$ fertilization suggesting that Mo uptake was enhanced by $\mathrm{Cl}^{-}$but reversed at high levels of $\mathrm{NO}_{3}^{-}$application.
\end{abstract}

Additional Index Words: Nicotiana tabacum $\mathrm{L} ., \mathrm{Cl}^{-}, \mathrm{Mo}, \mathrm{SO}_{4}$, solanesol, alkaloids, $\mathrm{P}, \mathrm{Ca}, \mathrm{Mg}$.

Evanylo, G.K., and J.L. Sims. 1987. Nitrogen and potassium fertilization effects on yield and quality of burley tobacco. Soil Sci. Soc. Am. J. 51:1536-1540.

$\mathrm{N}$ ITROGEN FERTILIZATION affects yield, quality, and usability of cured tobacco to a greater extent than does any other nutrient (McCants and Woltz, 1967; Atkinson and Sims, 1971; Miner and Sims, 1983). Yield and concentrations of most $\mathrm{N}$ constituents in the cured leaf are elevated as $\mathrm{N}$ fertilizer rates are increased up to about $215 \mathrm{~kg} \mathrm{~N} \mathrm{ha}^{-1}$, a level that normally produces maximum dry matter in burley tobacco. At higher $\mathrm{N}$ rates, $\mathrm{NO}_{3}^{-}$, and total $\mathrm{N}$ concentration of cured leaf may continue to increase; however, concentrations of total alkaloids, secondary amines, and other reduced $\mathrm{N}$ compounds usually increase at a much slower rate or not at all. Alkaloids and solanesol concentrations of tobacco are of interest from a human health standpoint since they are precursors, respectively, of carcinogenic nitrosamines ((USDHEW, 1982) or polynuclear aromatic hydrocarbons (Schlotzhaver et al., 1976).

Reports of the effects of $\mathrm{N}$ on leaf quality are often varied. Ammonium absorption by tobacco is known to increase $\mathrm{Cl}^{-}$accumulation (McCants et al., 1959;

'The investigation reported in this paper (86-3-198) was in connection with a project of the Kentucky Agric. Exp. Stn., Lexington, KY 40546-0091 and ARS-USDA. This paper is published with the approval of the Director of the Station and was supported in part by CR-ARS-USDA Cooperative Agreement 58-7B30-3-537. Received 26 Jan. 1987.

2 Former Postdoctoral Student (now Assistant Professor of Agronomy, VPI \& SU, Painter, VA 23420) and Professor of Agronomy, Dep. of Agronomy, Univ. of Kentucky, Lexington, KY 40546-0091, respectively.
McCants and Woltz, 1967), which is detrimental to tobacco quality. Fuqua et al. $(1974,1976)$ reported interactive effects of $\mathrm{NO}_{3}^{-}$and $\mathrm{Cl}^{-}$on their accumulation by plants. Increasing rates of $\mathrm{NO}_{3}^{-}$fertilizer increased nitrogenous constituents of leaf and smoke and greatly lessened the detrimental effects of $\mathrm{Cl}^{-}$on grades assigned by federal inspectors. Atkinson and Sims (1971) reported leaf quality to be lowered with either very low $\left(0-85 \mathrm{~kg} \mathrm{ha}^{-1}\right)$ or very high (300-450 $\mathrm{kg} \mathrm{ha}^{-1}$ ) applications of $\mathrm{N}$ fertilizer.

The response of tobacco to $K$ nutrition was reviewed recently (Sims, 1985). Yield increases with rates of $\mathrm{K}$ application up to $560 \mathrm{~kg} \mathrm{ha}^{-1}$ have been reported, but maximum yields were usually obtained with applications in the range of 60 to $225 \mathrm{~kg} \mathrm{ha}^{-1}$. Amounts of $\mathrm{K}$ greater than that required for maximum yields often resulted in improved quality, market value, and burning properties (Myhre et al., 1956; Nichols et al., 1956; McCants and Woltz, 1967; and Leggett et al., 1977). Increased K application decreased the accumulation of $\mathrm{Ca}$ and $\mathrm{Mg}$ by tobacco, but had erratic effects on carbohydrate and nitrogenous constituents of tobacco leaf.

Source of $\mathrm{K}$ is critical in tobacco nutrition. Potassium sulfate is the recommended $\mathrm{K}$ source, but it costs about 2.5 times more than $\mathrm{KCl}$ per unit of $\mathrm{K}$. Increased hygroscopic properties of tobacco leaf from excess $\mathrm{Cl}^{-}$uptake results in reduced burn rate and problems during storage and aging (Myhre et al., 1956; Nichols et al., 1956; McCants and Woltz, 1967). Greater growth and crop yields sometimes achieved with $\mathrm{KCl}$, compared with $\mathrm{K}_{2} \mathrm{SO}_{4}$, have been attributed to increased moisture of $\mathrm{Cl}^{-}$-treated leaf and to improved $\mathrm{Cl}^{-}$and/or Mo nutrition (Stout et al., 1951; Eivazi et al., 1983; Miner and Sims, 1983). A cured leaf $\mathrm{Cl}^{-}$level of $20 \mathrm{~g} \mathrm{~kg}^{-1}$ has been established by Zehler et al. (1981) as the upper limit of the acceptable range for combustibility of leaf. This is higher than the commonly accepted critical level of $10 \mathrm{~g} \mathrm{~kg}^{-1}$ found in the USA for burley and flue-cured tobaccos.

Although the individual effects of $\mathrm{N}$ and $\mathrm{K}$ fertilization on yields and quality-related components have been studied extensively, little data are available which examine the interactions of $\mathrm{N}$ and $\mathrm{K}$ fertilizers, including both $\mathrm{K}_{2} \mathrm{SO}_{4}$ and $\mathrm{KCl}$, on yield, price, and health-related constituents of burley tobacco. The objectives of this study were to determine the existence and/or significance of such interactions in tobacco nutrition.

\section{MATERIALS AND METHODS}

Field studies were conducted in 1983 and 1984 at the University of Kentucky Spindletop Research Farm on Maury silt loam soil (Typic Paleudalf). Ammonium nitrate at rates of 112,280 , and $448 \mathrm{~kg} \mathrm{~N}^{-1}$ and two $\mathrm{K}$ sources ( $\mathrm{KCl}$ and $\mathrm{K}_{2} \mathrm{SO}_{4}$ ) each at rates of $0,112,224$, and $448 \mathrm{~kg} \mathrm{~K} \mathrm{ha}^{-1}$ were employed in a split-split plot design and replicated three times. Nitrogen rates were assigned to the whole plots, $\mathrm{K}$ rates to the subplots, and $\mathrm{K}$ sources to the sub-subplots. All fertilizer was broadcast onto plowed ground and disked into the surface $7 \mathrm{~d}$ prior to transplanting burley tobacco $(\mathrm{Ni}$ - 
cotiana tabacum L. cv. KY 14). Molybdenum, as $\mathrm{Na}_{2}$ $\mathrm{MoO}_{4} \cdot 2 \mathrm{H}_{2} \mathrm{O}$, was supplied to all plots in the transplant water at the rate of $0.22 \mathrm{~kg} \mathrm{ha}^{-1}$. Individual plots consisted of four rows, 12-m-long and $1 \mathrm{~m}$ between rows. Plants were transplanted at a distance of $46 \mathrm{~cm}$ within rows. All cultural practices followed were conventional methods for burley tobacco production in Kentucky.

Composite soil samples ( 15 cores to the $15-\mathrm{cm}$ depth) were taken in each plot 2 weeks after transplanting in both 1983 and 1984. The samples were air dried and ground to pass a $2-\mathrm{mm}$ sieve in preparation for chemical analyses. Soil samples were subjected to saturation (Bower and Wilcox, 1965) extraction procedures for determination of solution phase $\mathrm{Cl}^{-}$.

The above ground parts of five tobacco plants were collected from each plot $35 \mathrm{~d}$ after transplanting for early leaf analysis. When mature, the whole plants in the two central rows of each plot were harvested and air-cured. Following curing, the leaves were stripped from the stalks, sorted into grade groups, and weighed for yield. U.S. Standard grades were assigned to each grade group by a USDA Tobacco Inspector and dollar values per kilogram (price) and per hectare (value) were calculated. Subsamples of cured leaf were collected, dried at $70^{\circ} \mathrm{C}$, and ground in a Wiley mill to pass a $0.425 \mu \mathrm{m}$ (40-mesh) sieve in preparation for chemical analyses. Cured leaf yields were reported on an oven-dry basis.

Chemical analyses of plant tissue were determined following methods used in the Univ. of Kentucky Agron. Dep.'s Anal. Serv. Lab. The leaf tissue samples were subjected to a nitric-perchloric acid digestion then analyzed for $\mathrm{K}, \mathrm{Ca}$, and $\mathrm{Mg}$ by atomic absorption spectroscopy. Leaf Mo levels were determined by means of the automated method of Eivazi et al., (1982) after ashing of the plant material. Total alkaloids, total $\mathrm{N}$, and $\mathrm{P}$ concentrations in cured leaf were determined on an autoanalyzer system following, respectively, methods of Harvey et al., (1969), Bradstreet (1965), and Technicon Industrial Method 348R-6-31-5, (Fiske and Subbarow, 1925). Chlorides were determined with a Buchler-Cotlove automatic titrator after extraction with water. Solanosal levels were determined by procedures described by Severson et al. (1977).

\section{RESULTS AND DISCUSSION}

Significant $\mathrm{N}$ rate $\times \mathrm{K}$ rate interactions influenced various cured leaf indices (Table 1). Yields increased with each increment of $\mathrm{N}$ fertilizer when no $\mathrm{K}$ was

Table 1. Mean squares (MS) and probability levels of significance from analysis of variance for effects of $\mathbf{N} \times \mathbf{K}$ interactions and orthogonal single degree of freedom comparisons on selected cured tobacco leaf variables.

\begin{tabular}{|c|c|c|c|c|c|c|c|}
\hline \multirow{2}{*}{$\begin{array}{l}\text { Source of } \\
\text { variation }\end{array}$} & \multirow[b]{2}{*}{ df } & \multicolumn{6}{|c|}{ Cured leaf variables } \\
\hline & & MS & $P>f$ & MS & $P>f$ & MS & $P>f$ \\
\hline & & \multicolumn{2}{|c|}{ N/Mo } & \multicolumn{2}{|c|}{$\underline{\mathrm{K} / \mathrm{MO}^{\prime}}$} & \multicolumn{2}{|c|}{$\underline{\mathrm{Mg} / \mathrm{Mo}}$} \\
\hline $\begin{array}{l}\mathbf{N} \times \mathbf{K} \\
\text { Error }\end{array}$ & $\begin{array}{l}6 \\
6\end{array}$ & $\begin{array}{r}1653.36 \\
535.11\end{array}$ & 0.10 & $\begin{array}{r}1197.27 \\
206.85\end{array}$ & 0.03 & $\begin{array}{r}24.64 \\
8.47\end{array}$ & 0.11 \\
\hline $\begin{array}{l}K_{1} \text { vs. all } \\
\text { others }\end{array}$ & & & & & & & \\
\hline$\underset{\text { Error }}{\times \mathbf{N}_{\mathbf{L}}}$ & $\begin{array}{r}1 \\
22\end{array}$ & $\begin{array}{r}1516.77 \\
231.82\end{array}$ & 0.02 & $\begin{array}{l}755.02 \\
134.34\end{array}$ & 0.03 & $\begin{array}{r}13.28 \\
5.19\end{array}$ & 0.12 \\
\hline & & \multicolumn{2}{|c|}{ Yield } & \multicolumn{2}{|c|}{ Price } & \multicolumn{2}{|c|}{ Solanesol } \\
\hline $\begin{array}{l}\mathrm{N} \times \mathrm{K} \\
\text { Error }\end{array}$ & $\begin{array}{l}6 \\
6\end{array}$ & $\begin{array}{l}0.0894 \\
0.0247\end{array}$ & 0.07 & $\begin{array}{l}304.99 \\
178.79\end{array}$ & 0.27 & $\begin{array}{r}25.51 \\
8.65\end{array}$ & 0.11 \\
\hline $\begin{array}{l}K_{1} \text { vs. all } \\
\text { others }\end{array}$ & & & & & & & \\
\hline$\underset{\text { Error }}{\times N_{L}}$ & $\begin{array}{r}1 \\
22\end{array}$ & $\begin{array}{l}0.1038 \\
0.0564\end{array}$ & 0.19 & $\begin{array}{r}1824.58 \\
580.78\end{array}$ & 0.09 & $\begin{array}{r}29.77 \\
3.41\end{array}$ & 0.01 \\
\hline
\end{tabular}

applied (Fig. 1). At higher K rates, (224 and $448 \mathrm{~kg} \mathrm{~K}$ $\mathrm{ha}^{-1}$ ) the response to $\mathrm{N}$ was erratic with yield reductions sometimes observed at the highest $\mathrm{N}$ rate.

Plant nutrient concentrations did not appear to be associated with the $\mathrm{N} \times \mathrm{K}$ yield response; however, the cured leaf ratios $\mathrm{N} / \mathrm{Mo}, \mathrm{K} / \mathrm{Mo}$, and $\mathrm{Mg} / \mathrm{Mo}$ were significant for the $\mathrm{N} \times \mathrm{K}$ interaction (Fig. 2; Table 1 ). While the values of the nutrient ratios increased in response to $\mathrm{N}$ fertilization, the increase was strengthened at the higher $\mathrm{K}$ rates. The response of nutrient ratios to $\mathrm{N}$ rate (linear) was especially different between the zero $K$ and all the other $K$ rates as noted by the orthogonal single degree of freedom comparisons. The demonstrated importance of nutrient balance as a yield-determining factor (Chapman, 1967; Kenworthy, 1973; Sumner, 1977) suggests that the balance of Mo with $\mathrm{N}, \mathrm{K}$, and/or Mg may have controlled the yield response.

Both cured leaf Mo concentrations (Fig. 3) and tobacco yields $\left(2.10\right.$ vs. $\left.1.96 \mathrm{Mg} \mathrm{ha}^{-1} ; P<0.15\right)$ were greater with $\mathrm{KCl}$ than with $\mathrm{K}_{2} \mathrm{SO}_{4}$ fertilization in both years. The differences in Mo concentrations between sources of $\mathrm{K}$ fertilizer were likely due to a lessening of the depressive effects of $\mathrm{SO}_{4}^{2-}$ on $\mathrm{MoO}_{4}^{2-}$ (Stout et al., 1951; Pal et al., 1976), to a $\mathrm{Cl}^{-}$enhancement effect (Eivazi et al., 1983), or both. The increased yield in the presence of $\mathrm{KCl}$ may be due to improved Mo or $\mathrm{Cl}^{-}$nutrition since the yield data are reported on an oven-dry weight basis (Fig. 4).

Cured leaf Mo concentrations decreased with increasing rates of both $\mathrm{K}$ sources; however, a greater reduction occurred with $\mathrm{K}_{2} \mathrm{SO}_{4}$ than with $\mathrm{KCl}$ (Fig. 3 ). The decreased concentrations at higher rates of $\mathrm{KCl}$ can be explained on the basis of dry weight dilution since yields and actual weight of Mo uptake (data not shown) were greater at the higher rates of $\mathrm{KCl}$. The decreased concentrations of Mo in the presence of $\mathrm{K}_{2} \mathrm{SO}_{4}$ may be attributed to both dry weight dilution and the competitive effects of $\mathrm{SO}_{4}^{2-}$ on $\mathrm{MoO}_{4}^{2-}(\mathrm{Pal}$ et al., 1976).

Nitrogen rates appeared to have an additive effect in contributing to the Mo decline with $\mathrm{K}$ rates. With $\mathrm{KCl}$, a slight increase in concentration, possibly due to $\mathrm{Cl}^{-}$enhancement, was obtained with $112 \mathrm{~kg} \mathrm{~K} \mathrm{ha}^{-1}$ at $\mathrm{N}$ rates of 112 and $280 \mathrm{~kg} \mathrm{~N}$ ha ${ }^{-1}$ (Fig. 3A). The elevated Mo at the second $\mathrm{K}$ level disappeared as the

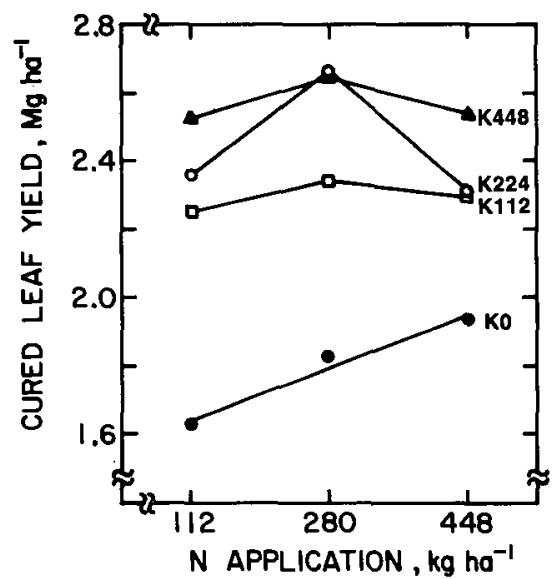

Fig. 1. Tobacco leaf yield response to $\mathbf{N}$ fertilizer rates at each $\mathrm{K}$ rate. 

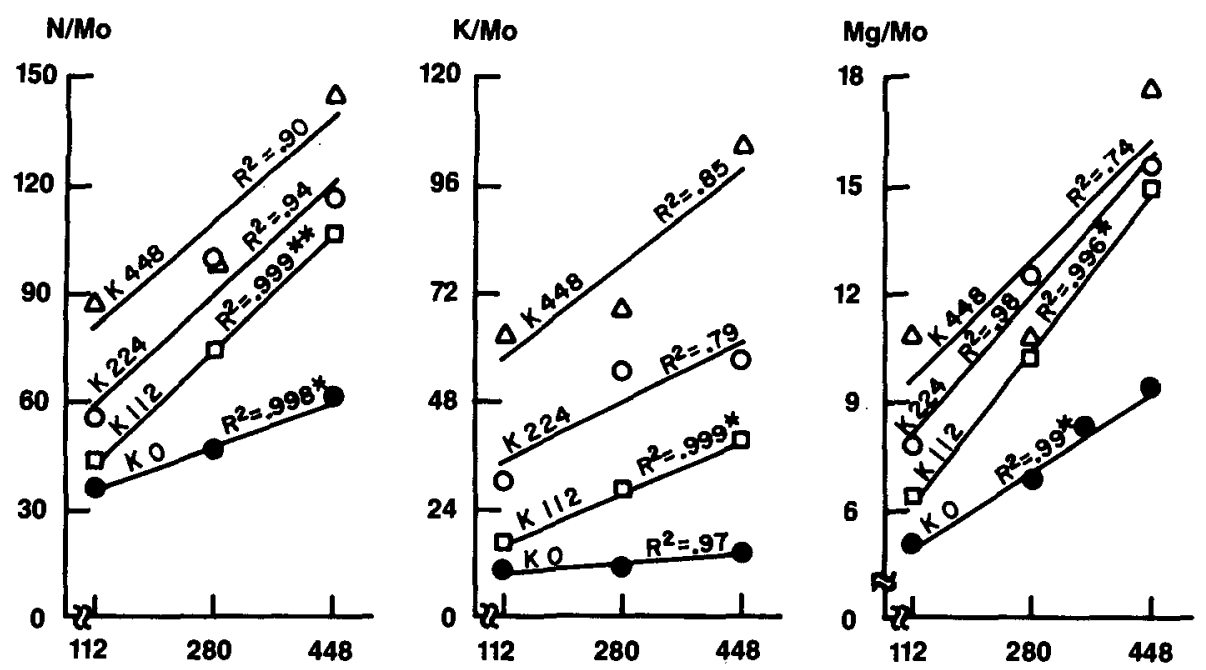

NITROGEN FERTILIZER RATE, $\mathrm{kg} \mathrm{ha}^{-1}$

Fig. 2. Cured leaf $\mathrm{N} / \mathrm{Mo}, \mathrm{K} / \mathrm{Mo}$, and $\mathrm{Mg} / \mathrm{Mo}$ ratios as a function of $\mathrm{N}$ and $\mathrm{K}$ fertilizer levels. *, * Significant at 0.05 and 0.01 probability levels, respectively.

$\mathrm{N}$ rate was raised to $448 \mathrm{~kg} \mathrm{~N} \mathrm{ha}^{-1}$. Since $\mathrm{NO}_{3}^{-}$is known to interfere with $\mathrm{Cl}^{-}$uptake (McCants and Woltz, 1967; Fuqua et al., 1974, 1976), the application of the highest $\mathrm{N}$ rate may have reduced the level of $\mathrm{Cl}^{-}$uptake thereby reducing the $\mathrm{Cl}^{-}$enhancement effort on Mo. The $\mathrm{NO}_{3}^{-}-\mathrm{Cl}^{-}$antagonism is illustrated in Fig. 4 where the effect of increasing $\mathrm{N}$ rates on cured leaf $\mathrm{Cl}^{-}$concentration can be seen. Tissue $\mathrm{Cl}^{-}$concentrations were reduced by increasing $\mathrm{N}$ rates under $\mathrm{KCl}$ fertilization, but no differences in $\mathrm{Cl}^{-}$concentrations were effected by $\mathrm{N}$ when the $\mathrm{SO}_{4}^{2-}$ source was employed.

Quality of cured tobacco leaf, as evaluated by leaf price, responded to the $\mathrm{N} \times \mathrm{K}$ interaction (Fig. 5). A greater rise in price was obtained with increasing $N$ rate when no $\mathrm{K}$ was applied than at the three highest $\mathrm{K}$ rates (Table 1 ). Tobacco leaf price, which generally improved with addition of intermediate $\mathrm{N}$ rates $(100-$ $300 \mathrm{~kg} \mathrm{~N} \mathrm{ha}^{-1}$ ), is usually reduced by levels of $\mathrm{N}$ corresponding to the highest rate in the study (Atkinson and Sims, 1971); however, even at the $448 \mathrm{~kg} \mathrm{ha}^{-1} \mathrm{~N}$ rate only positive responses were elicited. The price response may be partly due to the lowering of $\mathrm{Cl}^{-}$by $\mathrm{NO}_{3}^{-}$, although this would not account for the positive $\mathrm{N}$ effect on price observed under $\mathrm{K}_{2} \mathrm{SO}_{4}$ fertilization.

Plant uptake of $\mathrm{Cl}^{-}$depended primarily upon its concentration in the soil. Early and cured tobacco leaf

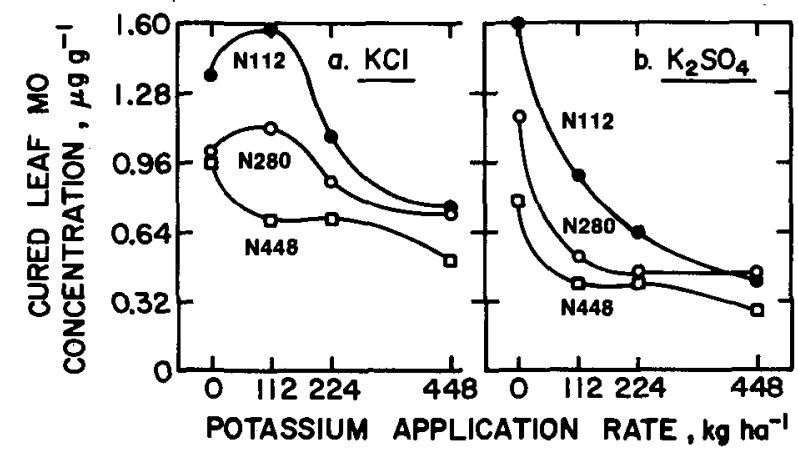

Fig. 3. Effect of source and rate of $K$ fertilizer on cured leaf Mo concentration at various rates of $N$.
$\mathrm{Cl}^{-}$concentrations have been plotted as functions of saturated paste $\mathrm{Cl}^{-}$concentrations sampled to a $15-$ $\mathrm{cm}$ soil depth (Fig. 6a and b, respectively). While greater concentrations of $\mathrm{Cl}^{-}$were present in early season leaf in 1983 than in 1984, the greater growth experienced by the 1984 crop (due to more favorable soil moisture) resulted in greater $\mathrm{Cl}^{-}$concentrations in the cured leaf. This is probably explained by the dependence of $\mathrm{Cl}^{-}$uptake on plant metabolism (Mengel and Kirkby, 1979). Despite its good growth and high yields, the 1984 burley crop may be considered of unsatisfactory quality due to its high $\mathrm{Cl}^{-}$content (Zehler et al., 1981). While good correlations between saturated paste $\mathrm{Cl}^{-}$concentrations and early season leaf $\mathrm{Cl}^{-}$concentrations were obtained, the use of a soil test in the humid east to predict how $\mathrm{Cl}^{-}$may accumulate in cured leaf is questionable.

The observation that cured leaf total alkaloid concentrations were increased by $\mathbf{K}$ fertilization (Table 2) is contradictory to results of other studies (Hutcheson et al., 1959; Leggett et al., 1977) in which negative correlations between the rate of $\mathrm{K}$ fertilizer and the concentration of nicotine or total alkaloids in cured leaves were found. The previously reported effects of $\mathrm{K}$ on total alkaloids may have been due to dilution

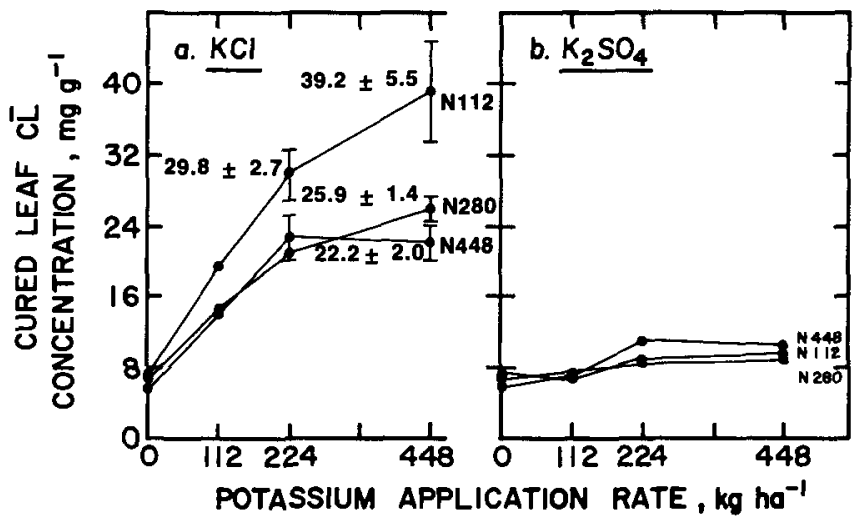

Fig. 4. Cured leaf $\mathrm{Cl}^{-}$concentration as affected by $\mathrm{KCl}$ and $\mathrm{K}_{2} \mathrm{SO}_{4}$ at various rates of $\mathrm{N}$. I = standard error of mean. 


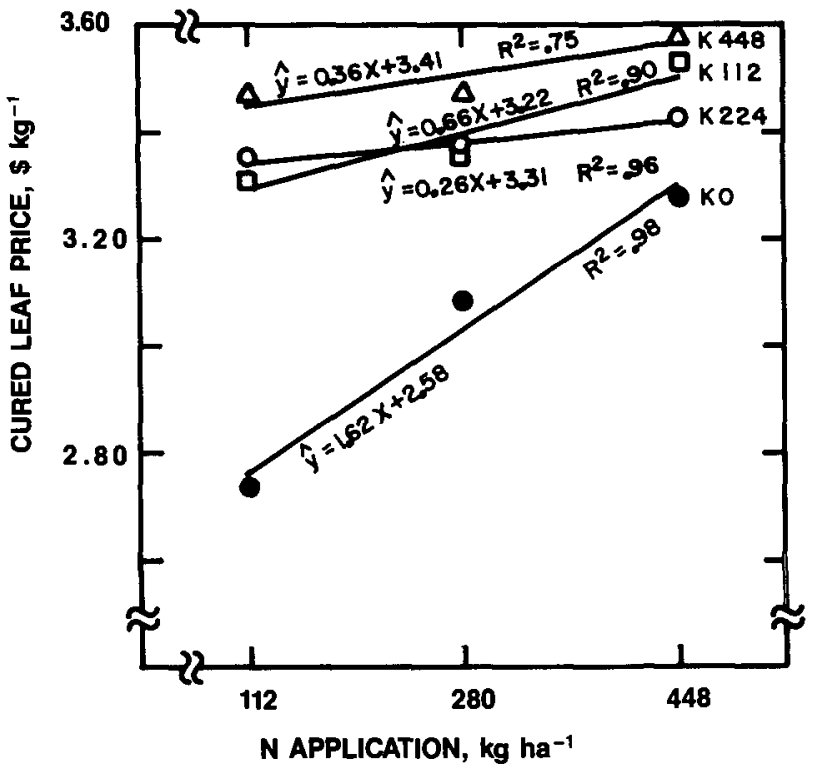

Fig. 5. Influence of rates of $N$ and $K$ on cured leaf price.

by dry matter since there are no known functions of $\mathrm{K}$ in the synthesis of nicotine. Solanesol levels were increased by $\mathrm{N}$ when no $\mathrm{K}$ was applied, but were reduced by increased $\mathrm{N}$ with increased $\mathrm{K}$ application (Fig. 7). The $\mathrm{N} \times\left(\mathrm{K}_{1}\right.$ vs. $\mathrm{K}_{2}, \mathrm{~K}_{3}$, and $\left.\mathrm{K}_{4}\right)$ contrast was significant at the 0.01 level of probability.

\section{CONCLUSIONS}

The $\mathrm{N}$ rate $X \mathrm{~K}$ rate interaction has been shown to influence tobacco yield and quality components which are critical in determining the value of the crop. Yield, price, and solanesol concentrations were increased by $\mathrm{N}$ when $\mathrm{K}$ was limiting; however, as $\mathrm{K}$ rates were increased, $\mathrm{N}$ marginally affected yield and price and tended to decrease solanesol. The yield response to the $\mathrm{N} \times \mathrm{K}$ interaction may have been related to Mo nutritional balance. Molybdenum uptake appeared to be enhanced by $\mathrm{Cl}^{-}$and depressed by $\mathrm{NO}_{3}^{-}$(which

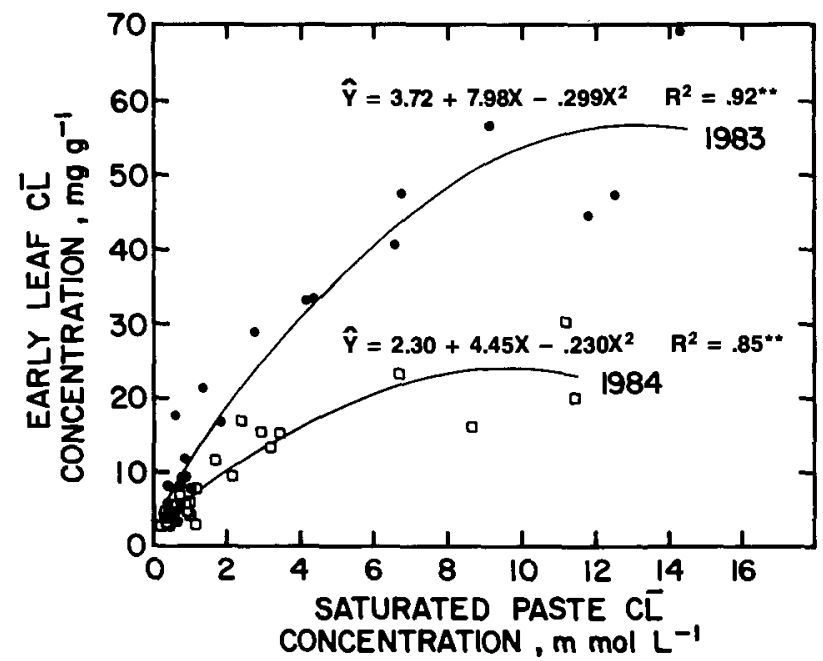

Fig. 6a. Early sampled tobacco Ieaf $\mathrm{Cl}^{-}$concentration as a function of saturated-paste $\mathrm{Cl}^{-}$concentration at the $0-15 \mathrm{~cm}$ soil depth. ${ }^{* *}$ Significant at $P<0.01$. $N=24$.

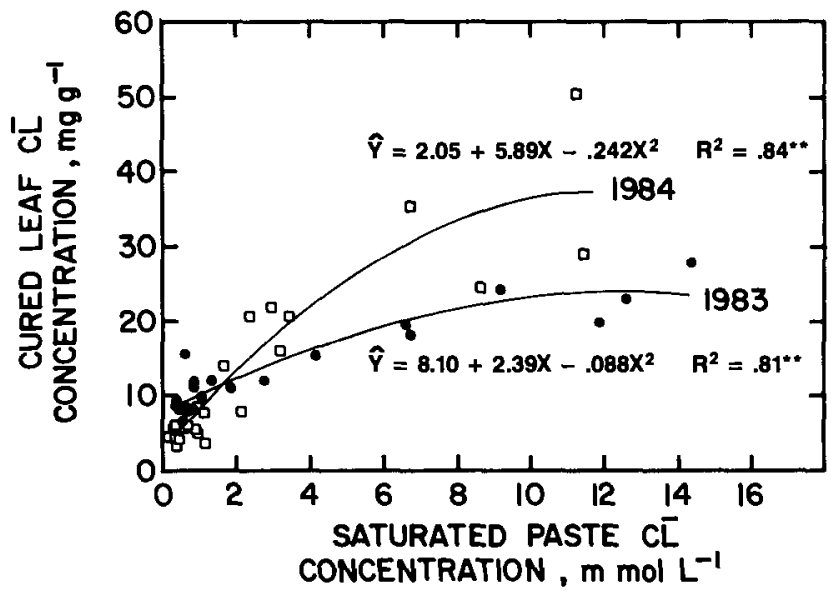

Fig. 6b. Cured-leaf $\mathrm{Cl}^{-}$concentration as a function of saturatedpaste $\mathrm{Cl}^{-}$concentration at the $0-15 \mathrm{~cm}$ soil depth. ** Significant at $\mathrm{P} \leq 0.01$. $\mathrm{N}=24$.

competes with $\mathrm{Cl}^{-}$for uptake). Leaf $\mathrm{Cl}^{-}$accumulated as a function of saturated paste $\mathrm{Cl}^{-}$concentration but soil $\mathrm{Cl}^{-}$as a tool for predicting cured leaf $\mathrm{Cl}^{-}$concentration (and quality) appears to be of little value under varying environmental conditions.

Table 2. Cured leaf solanesol and total alkaloid concentrations as influenced by $K$ fertilization.

\begin{tabular}{|c|c|c|c|c|c|}
\hline \multirow[b]{2}{*}{ Leaf constituent } & \multicolumn{5}{|c|}{$\mathrm{K}$ rate $\left(\mathrm{kg} \mathrm{ha}^{-1}\right)$} \\
\hline & 0 & 112 & 224 & 448 & \\
\hline & & $-\varepsilon$ & & - & \\
\hline $\begin{array}{l}\text { Total alkaloids } \\
\text { Solanesol }\end{array}$ & $\begin{array}{l}37.1 \\
15.5\end{array}$ & $\begin{array}{l}42.0 \\
18.5\end{array}$ & $\begin{array}{l}42.5 \\
17.3\end{array}$ & $\begin{array}{l}42.0 \\
19.0\end{array}$ & $\stackrel{* *}{*}$ \\
\hline
\end{tabular}

*,** Significant at the 0.05 and 0.01 probability levels, respectively.

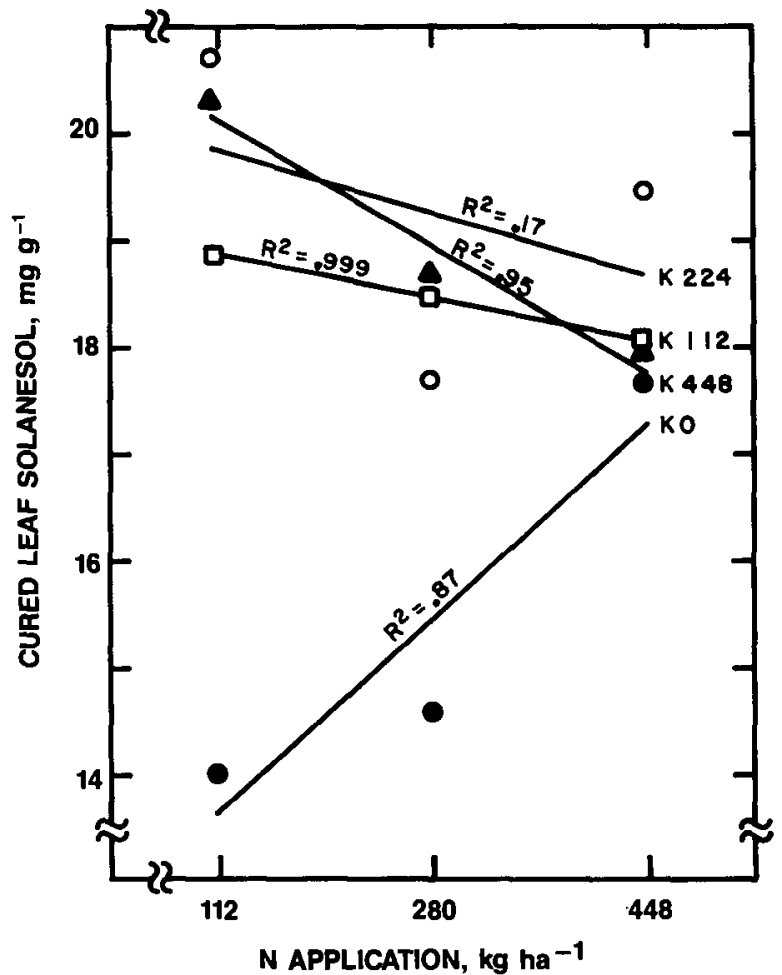

Fig, 7. Influence of rates of $N$ and $K$ on cured leaf solanesol concentration. 


\section{ACKNOWLEDGMENT}

Appreciation is expressed to Dr. Harold Burton for the solanesol determinations.

\section{REFERENCES}

Atkinson, W.O., and J.L. Sims. 1971. Nitrogen composition of burley tobacco. II. Influence of nitrogen fertilization, suckering practice, and harvest date on yield, value, and distribution of dry matter among plant parts. Tob. Sci. 15:63-66.

Bower, C.A., and L.V. Wilcox. 1965. Soluble salts. In C.A. Black (ed.) Methods of soil analysis. Part 2. 9:933-951.

Bradstreet, R.b. 1965. The Kjeldahl method for organic nitrogen. Academic Press, New York.

Chapman, H.D. 1967. Plant analysis values suggestive of nutrient status of selected crops. p. 77-92. In G.W. Hardy et al. (ed.) Soil testing and plant analysis. Part 2. SSSA Spec. Pub. No. 2. Soil Science Society of America, Madison, WI.

Eivazi, F., J.L. Sims, M. Casey, G.D. Johnson, and J.E. Leggett. 1983. Growth and molybdenum concentration of burley tobacco as influenced by potassium, molybdenum, and chloride in transplant fertilizer solutions. Can. J. Plant Sci. 63:531-538.

Eivazi, F., J.L. Sims, and J. Crutchfield. 1982. Determination of molybdenum in plant materials using a rapid, automated method. Commun. Soil Sci. Plant Anal. 13:135-150.

Fiske, O.H., and Y. Subbarow. 1925. The colorimetric determination of phosphorous. J. Biol. Chem. 66:375-400.

Fuqua, B.D., J.E. Leggett, and J.L. Sims. 1974. Accumulation of nitrate and chloride by burley tobacco. Can. J. Plant Sci. 54:167174.

Fuqua, B.D., J.L. Sims, J.E. Leggett, J.F. Benner, and W.O. Atkinson. 1976. Nitrate and chloride fertilization effects on yield and chemical composition of burley tobacco leaves and smoke. Can. J. Plant Sci. 56:893-899.

Harvey, W.R. H.M. Stahr, and W.C. Smith. 1969. Automated determination of reducing sugars and nicotine alkaloids on the same extract of tobacco leaf. Tob. Sci. 13:13-15.

Hutcheson, T.B., W.G. Woltz, and S.B. McCaleb. 1959. Potassiumsodium interrelationships: I. Effects of various rates and combinations of $\mathrm{K}$ and $\mathrm{Na}$ on yield, value, and physical and chemical properties of flue-cured tobacco grown in the field and greenhouse. Soil Sci. 87:28-36.

Kenworthy, A.L. 1973. Leaf analysis as an aid in fertilizing orchards. p. 381-392. In L.M. Walsh, and J.D. Beaton (ed.) Soil testing and plant analysis. Soil Science Society of America, Madison, WI.

Leggett, J.E., J.L. Sims, D.R. Gossett, U.R. Pal, and J.F. Benner. 1977. Potassium and magnesium nutrition effects on yield and chemical composition of burley tobacco leaves and smoke. Can. J. Plant Sci. 57:159-166.

McCants, C.B., E.O. Skogley, and W.G. Woltz. 1959. Influence of certain soil fumigation treatments on the response of tobacco to ammonium and nitrate forms of N. Soil Sci. Soc. Am. Proc. $23: 466-469$.

McCants, C.B., and W.G. Woltz. 1967. Growth and mineral nutrition of tobacco. Adv. Agron. 19:211-265.

Mengel, K., and E.A. Kirby. 1979. Further elements of importance: Chlorine. p. 495-498. In Principles of plant nutrition. International Potash Institute, Norblaufen-Bern, Switzerland.

Miner, G.S., and J.L. Sims. 1983. Changing fertilization practices and utilization of added plant nutrient elements for efficient production of burley and flue-cured tobacco. Recent Adv. Tob. Sci. 9:4-76.

Myhre, D.L., O.J. Attoe, and W.B. Ogden. 1956. Chlorine and other constituents in relation to tobacco leaf-burn. Soil Sci. Soc. Am. Proc. 20:547-551.

Nichols, B.C., D.R. Bowman, and J.E. McMurtrey, Jr. 1956. Fertilizer tests with burley tobacco with special reference to potash. Tenn. Agric. Exp. Stn. Bull. 252.

Pal, U.R., D.R. Gossett, J.L. Sims, and J.E. Leggett. 1976. Molybdenum and sulfur nutrition effects on nitrate reduction in burley tobacco. Can. J. Bot. 54:2014-2022.

Schlotzhaver, W.S., R.F. Severson, O.T. Chortyk, and J.C. Higman. 1976. Pyrolytic formation of polynuclear aromatic hydrocarbons from petroleum other extractable constituents of flue-cured tobacco leaf. J. Agric. Food Chem. 24:992-997.

Severson, Ray F., R.F. Arrendale, J.F. Chaplin, and R.E. Williamson. 1977. Use of the pale-yellow tobacco to reduce smoke polynuclear aromatic hydrocarbons. J. Agric. Food Chem. 27:896900.

Sims, J.L. 1985. Potassium nutrition of tobacco. p. 1023-1043. In R.D. Munson (ed.) Potassium in agriculture. American Society of Agronomy, Crop Science Society of America, and Soil Science Society of America, Madison, WI.

Stout, P.R., W.R. Meagher, G.A. Pearson, and C.M. Johnson. 1951. Molybdenum nutrition of crop plants. I. The influence of $\mathrm{PO}_{4}^{3-}$ and $\mathrm{SO}_{4}^{2-}$ on the absorption of molybdenum from soils and solution cultures. Plant Soil 3:51-87.

Sumner, M.E. 1977. Use of the DRIS system in foliar diagnosis of crops at high yield levels. Commun. Soil Sci. Plant Anal. 8(3):251268.

U.S. Department of Health, Education, and Welfare (USDEW). 1982. The health consequences of smoking, cancer: A report of the Surgeon General. DHHS Pub. (PHS) 82-50179. U.S. Government Printing Office, Washington, DC.

Zehler, E, H. Kreipe and P.A. Gething 1981. Tobacco (Nicotiana tabacum). p. 63-64. IPI Res. Topics 9. International Potash Institute, Bern, Switzerland. 